\title{
DNA Repair Gene
}

National Cancer Institute

\section{Source}

National Cancer Institute. DNA Repair Gene. NCI Thesaurus. Code C19676.

DNA Repair Genes encode DNA Repair Proteins, involved in enzymatic restoration of

DNA structure after chemical, radiation, or spontaneous damage. $(\mathrm{NCl})$ 